Boston University School of Law

Scholarly Commons at Boston University School of Law

Faculty Scholarship

1995

Medicine, Death, and the Criminal Law

George J. Annas

Follow this and additional works at: https://scholarship.law.bu.edu/faculty_scholarship

Part of the Health Law and Policy Commons 


\section{LEGAL ISSUES IN MEDICINE}

\section{MEDICINE, DEATH, AND THE CRIMINAL LAW}

George J. Annas, J.D., M.P.H.

ERRORS in medicine are common and are at least partly responsible for the deaths of 180,000 patients a year. ${ }^{1,2}$ There is increasing concern about medical errors and the steps that should be taken to prevent them. ${ }^{1}$ Until recently, hospitals have addressed errors after the fact, through mortality and morbidity conferences, incident reports, and the like, rather than before the fact, through attention to systems defects and prevention. Likewise, medical-malpractice litigation can be filed only after an injury has occurred. Malpractice litigation is intended to create incentives to improve the quality of medical care by making physicians and hospitals accountable for their actions, but works by providing compensation for injury. A third mechanism, sanction by state medical licensing boards, can have a more direct effect, since action can be taken on the basis of a physician's danger to patients - even if consistently negligent acts have not resulted in injuries. Nonetheless, licensing boards have not sought out marginally competent physicians and usually do not take action until there has been grievous harm to a patient or until a physician has been convicted of a crime. ${ }^{1}$

Criminal charges related to the practice of medicine have primarily involved insurance fraud (including Medicare and Medicaid fraud), sexual abuse of patients, or illegal use or prescription of controlled substances. Criminal prosecution is generally thought to serve three goals: deterrence, retribution, and rehabilitation. In medicine, rehabilitation is often considered the only goal of sanctions by licensing boards. The ineffectiveness of such sanctions and malpractice litigation in deterring error-prone behavior might make the criminal law seem a necessary mechanism for prevention (deterrence), and the criminal law is, of course, the only legitimate social mechanism we have for punishment (retribution) in cases involving intentional or deliberate disregard for patients' safety.

Criminal prosecution of physicians for the deaths of patients remains extraordinarily rare. ${ }^{3}$ Three recent cases, however, provide an opportunity to examine the use of the criminal law as a response to egregious medical acts that result in death. The three cases, from New York, Colorado, and Wisconsin, represent a range of criminal prosecutions. As the Washington Post stated in an editorial, "These three cases have particularly shocking facts and terrible consequences for which civil and professional penalties may not be enough."

\section{The New York Case}

Dr. Gerald Einaugler's patient was a 78-year-old woman with end-stage renal disease, diabetes, cardio- vascular disease, and senility. She was transferred from Brooklyn's Interfaith Medical Center to a nursing home across the street in May 1990. ${ }^{5}$ At the nursing home, Dr. Einaugler mistook the patient's peritoneal-dialysis catheter for a gastrostomy tube and directed the staff to feed the patient through it. She received several feedings through the dialysis catheter before the mistake was discovered by a nurse. After he had been notified of the mistake, Dr. Einaugler telephoned the chief nephrologist at the medical center, who advised him to "get the patient into the hospital." After talking to the nephrologist, Dr. Einaugler went to the nursing home to examine the patient but decided to delay her transfer. A New York appeals court stated, "Although the defendant knew that peritonitis could be fatal if untreated, he did not direct the patient's transfer to the hospital for more than 10 hours after his conversation with the nephrologist.." ${ }^{\prime 6}$ On admission, peritonitis was diagnosed, and the patient died within days. Testimony by experts for both the prosecution and defense

established that proper medical care required treating the patient as soon as peritonitis was suspected, and following the advice of the nephrologist. Thus the evidence established that the defendant was aware of, and consciously disregarded, a substantial risk of serious physical injury to the patient by delaying her transfer to the hospital, and that his conduct constituted a gross deviation from the standard of conduct a reasonable person would observe in the situation. ${ }^{6}$

Because of the delay, in July 1993 Dr. Einaugler was convicted of reckless endangerment of his patient and willful violation of New York's health laws. In October 1994, the appeals court unanimously upheld the verdict, ruling that the jury could have found the above account factual beyond a reasonable doubt. ${ }^{6}$ In addition to supporting the conviction for reckless endangerment in the second degree, the appeals court found that the physician's action violated New York's public health laws, which prohibit a physician from "willfully" committing "an act of neglect." "Willful neglect is defined as "knowingly" failing to "provide timely, consistent, safe, adequate, and appropriate services, treatment, and/or care to a patient or resident of a residential health care facility." ${ }^{\prime \prime}$

Medical organizations, including the American Medical Association, have called the prosecution of Dr. Einaugler an inappropriate response to an error in medical judgment. As one leading legal commentator noted, "You know it's an unusual case when the American Medical Association's defense of a physician is that what he did was medical negligence." In this case, however, the physician was accused of a conscious (i.e., intentional) disregard for the patient's safety in failing to transfer her to a hospital for treatment, not an error in medical judgment or a mistake in properly identifying a feeding tube. As the appeals court said simply and unanimously, this case "does not support the proposition that medical professionals need fear the prospect of unwarranted criminal prosecutions for honest errors of medical judgment." $"$ The prosecutor's theory, that Dr. Einaugler delayed his patient's transfer in an 
attempt to cover up his original negligence, was consistent with a conscious disregard for the patient's safety, ${ }^{6}$ and the appeals court decided that the jury had ample evidence to reach this verdict. Dr. Einaugler was sentenced to spend 52 weekends in jail. ${ }^{5}$ The sentence was later stayed, in March 1995, pending a further hearing in U.S. District Court.

The law defines reckless endangerment as the conscious disregard of a known and substantial likelihood of injury to the patient. If the patient dies as a result, a charge of manslaughter is appropriate. Such a charge was not made in this case, perhaps because the district attorney did not believe he could prove beyond a reasonable doubt that had the patient been transferred sooner, she would have survived. An even more recent case in New York provides an example of a case in which a manslaughter charge seems appropriate. In July and August 1995, Dr. David Benjamin was tried for manslaughter on the basis of allegations that he knowingly and intentionally performed a procedure (a late abortion) that he did not have the skills to perform and that his deliberate indifference to the health and safety of his patient led directly to her death from excessive bleeding. ${ }^{8}$ The physician's license to practice medicine had already been revoked for "gross incompetence and negligence" in connection with five previous cases involving life-threatening uterine perforations. This death occurred during the three weeks he was allowed to continue practicing medicine, before the revocation became final. ${ }^{8}$

\section{The Colorado Gase}

On July 8, 1993, Dr. Joseph J. Verbrugge, Jr., an anesthesiologist, fell asleep during a mastoidectomy at St. Joseph Hospital in Denver. The patient, eight-year-old Richard Leonard, died. Judith F. Schulman, an administrative-law judge, conducted a hearing for the Colorado Board of Medical Examiners. She found that Dr. Verbrugge had been "grossly negligent" in performing a series of specific acts "covering virtually every aspect" of the patient's care. ${ }^{9}$ In her words, the "respondent . . . failed to calibrate the anesthesia machine's oxygen analyzer . . . failed to monitor properly during surgery ... . failed to adequately respond to evidence of a developing crisis during surgery . . . failed to remain awake and otherwise alert and vigilant at certain times during the surgery. . . Charting ... in certain cases was also falsified." ${ }^{, 9}$,

The boy's temperature had risen to $107^{\circ} \mathrm{F}\left(41.6^{\circ} \mathrm{C}\right)$, and his breathing tube was half blocked with mucus. It is unclear exactly how long Dr. Verbrugge was asleep or why the nurses did not wake him up. Contending that the child died of malignant hyperthermia, Dr. Verbrugge argued that he should not be held responsible. The judge, however, found that it was his lack of vigilance that "in all likelihood directly resulted" in the patient's death, that even if the child had had malignant hyperthermia, he should have had a 90 percent chance of survival, and that "if the main problem was an obstructed airway, early recognition would have resolved the problem completely." ${ }^{\prime \prime}$ Dr. Verbrugge's medical li- cense, which had been summarily suspended in July 1993, was revoked on the basis of these findings. On April 4, 1995, Dr. Verbrugge was charged with manslaughter in connection with the boy's death. ${ }^{10}$ It was also alleged that he had fallen asleep during at least six other operations from September 1990 through March 1993, although no criminal charges were filed regarding those allegations..$^{10}$ The trial has not yet been held.

\section{The Wisconsin Case}

The Wisconsin case involved two women, 29-yearold Karin Smith, who died in 1995, and 39-year-old Dolores Geary, who died in 1993; both died of treatable cervical cancer after the misreading of several Pap smears. Smith had reported problems at 15 office visits over a three-year period during which practitioners at her health maintenance organization (HMO) had performed three biopsies and obtained three Pap smears, all but one of which (the last) were misread. Geary, a member of the same HMO, also had two Pap smears reported as normal before a 1991 hysterectomy, during which advanced cervical cancer was discovered. The HMO contracted with Chem-Bio Corporation to read the smears in both cases. A six-member inquest jury heard evidence that the laboratory's director, a physician, paid a technician on a piecework basis to read Pap smears. The technician had read 31,000 smears for Chem-Bio and 16,000 for other laboratories in 1989, an annual rate four times higher than that recommended by the American Society of Cytology. ${ }^{11}$

On April 7, 1995, the inquest jury recommended that criminal charges be brought against the director, the technician, and the laboratory. The district attorney, however, charged only the laboratory - with reckless homicide. The trial date has been set for December 4 . Of course, if the corporation is found guilty, it cannot be put in prison; the punishment will most likely be a fine. The physician agreed that for the next six years, he will not serve as a laboratory director, will not supervise any cytotechnologists, and will not do any work in which he is responsible for quality control. ${ }^{12}$ The technician agreed not to read Pap smears on a piecework basis, not to work more than 42 hours a week, and to obey all regulations that govern the number of Pap smears a technician can read in a day. Malpractice suits against the laboratory director, the cytotechnologists, and several other physicians were settled in the amounts of $\$ 6.3$ million for Mrs. Smith's family and $\$ 3.5$ million for Mrs. Geary's family. ${ }^{11}$

\section{Criminal Standards in Medicine}

These three cases illustrate different applications of the criminal law. In terms of the more traditional remedies, only one has resulted in a decision by a licensing board to limit a physician's ability to practice medicine (the Colorado case), and only one (the Wisconsin case) has resulted in a completed malpractice action. In fact, no civil suit was possible in the New York case, because the deceased had no family and apparently had no estate. Only one of these cases may have involved financial motives to provide grossly substand- 
ard care (the Wisconsin case). Nonetheless, in all the cases, criminal charges were brought in instances in which patients died.

Although criminal prosecutions of physicians are extremely rare, when they do occur, they almost always involve charges of reckless or intentional gross deviation from the accepted standard of care. ${ }^{3,13}$ This standard is much higher than that used in medical-malpractice lawsuits, which, to be successful, require only proof of a breach of duty resulting in harm to the patient. Breach of duty is the failure to provide the level of care or treatment that would have met the standard of care - that is, the level that would have been considered acceptable in the medical community. Deviation from the standard of care, including a mistake of fact or judgment, is usually denoted simply as negligence or medical malpractice. Unlike a criminal charge, which must be proved beyond a reasonable doubt, a charge of malpractice need be proved only by a preponderance of the evidence.

The Massachusetts Supreme Judicial Court has put physicians' concern about criminal liability in proper perspective: "Little need be said about criminal liability: there is precious little precedent, and what there is suggests that a doctor will be protected if he acts on a good faith judgment that is not grievously unreasonable by medical standards." 14 Thus, a physician will not be held criminally liable for the death of a patient if that death is the result of a good-faith error of judgment or an inadvertent mistake., ${ }^{3,15}$ In the rare cases of criminal prosecution, charges have usually been brought because a pattern of deaths and reckless disregard for patients' safety has emerged and, for some reason, the physician's license has not been revoked.

In a recent California case, for example, a physician was convicted of second-degree murder for intentional conduct resulting in the deaths of nine patients over an 11-year period. The court found that the doctor was "subjectively aware his methods of home and office deliveries were life-endangering, but consciously and deliberately disregarded these risks." 16 The court explained the difference between second-degree murder and manslaughter as follows:

Second degree murder based on malice is committed when the defendant does not intend to kill, but engages in conduct which endangers the life of another, and acts deliberately with conscious disregard for life. An essential distinction between [second degree murder and] manslaughter based on criminal negligence, is that in the former the defendant subjectively realized the risk to human life created by his conduct, whereas in the latter the defendant's conduct objectively endangered life, but he did not subjectively realize the risk. ${ }^{16}$

Even a large number of deaths will not be sufficient for a criminal conviction unless the prosecution can demonstrate the requisite intent or recklessness, which will usually also involve identifying a specific standard of care that the physician grossly violated and that caused the deaths. For example, an appeals court in New Jersey reversed the conviction of a physician on the charge of involuntary manslaughter for the deaths of 12 of his patients from hepatitis contracted through intravenous injections. ${ }^{17}$ The primary reason for the re- versal was that the state was unable to prove the precise manner in which hepatitis was transmitted to the patients (the state suggested four possible theories of causation, including the multiple use of saline bottles and tubing). Thus, the state could not demonstrate that the defendant had recklessly and grossly deviated from the accepted standard in the care of his patients, because it could not show (beyond a reasonable doubt) that all the ways in which the virus would have been transmitted involved criminal negligence. ${ }^{17}$

A physician can be prosecuted for a single death that was caused by intentional or reckless disregard of life, but such prosecutions usually involve cases in which there has been repeated and intentional disregard for a patient's welfare over a period of time. In a Pennsylvania case, for example, a physician was found guilty of involuntary manslaughter after issuing dozens of prescriptions for controlled substances, including barbiturates, which led to the death of his patient. The appeals court found that the physician "consciously disregarded a substantial and unjustified risk, which disregard involved a gross deviation from the standard of conduct a reasonable person would have observed."18 The case of Dr. Verbrugge is typical of the few cases involving charges of involuntary manslaughter that have been brought against physicians, in that it involved a series of acts showing conscious disregard for a patient's safety. Prosecutors seem unwilling to bring charges of criminal negligence on the basis of only one act, probably because they think it will be difficult to convince a jury that an isolated act demonstrates intentional indifference to a patient's welfare.

In this respect, the case of Dr. Einaugler is somewhat unusual. He was charged not with the death of his patient but with the failure to transfer her to the hospital for proper treatment in a timely manner. His misidentification of the dialysis tube was thus viewed as an inadvertent error, whereas his failure to act to protect the patient after he discovered the error was considered a conscious decision to risk her life for no medical reason. It is disturbing that the New York licensing board found that Dr. Einaugler's care of this patient was not substandard and that there was no need to discourage such treatment. Prosecutors may feel an additional obligation to the public to take action when professional self-regulation does not function to protect the public.

Of the three cases, the Wisconsin case is the most unusual, yet also the one that may exemplify the types of criminal cases that will become more frequent in our current system of market-driven medical care. The prosecutor did not bring criminal charges against the laboratory director, apparently because he believed that the public could be adequately protected by the director's agreement not to run a laboratory for six years and because at least some punishment had been meted out through malpractice litigation. The prosecutor did bring criminal charges against the laboratory.

We will continue to see criminal cases, and they are likely to differ from the current cases involving fraud, sexual abuse, and illegal drug prescription in frequency rather than in kind. ${ }^{19}$ Some new cases, however, may in- 
volve patients' deaths from acts or omissions motivated by the desire to cut costs. Making more money is not a matter of medical judgment. If a healthy bottom line becomes more important than the health of the patient, it will seem perfectly reasonable for prosecutors to use the criminal law to protect patients and punish offenders. Prosecutors must, however, demonstrate that the physicians involved knew their cost-cutting measures would put patients' lives at risk and consciously or recklessly disregarded that risk. It may not be possible to provide such proof in most cases. However, individual officers or directors of medical organizations could be charged with manslaughter if they pursued policies they knew would result in death or if they were aware of the substantial risk of death and consciously disregarded it in setting organizational rules. Obviously, corporations and managers who are not physicians cannot use the defense of good-faith medical judgment, since nonphysicians cannot make medical judgments.

\section{Conclusions}

When a physician's egregious medical acts result in the death of a patient, the public expects that some action will be taken against the physician. Therefore, prosecutors may be more likely to turn to criminal prosecutions if proposals are enacted to limit civil liability by making it much harder for injured patients to sue negligent physicians. Also, if medical licensing boards continue to be ineffective in imposing sanctions against grossly negligent and incompetent behavior by physicians, prosecutors may conclude that criminal charges are the only way to protect the public.

The medical profession's reputation for acting in the best interests of patients is undermined not only by the publicity that criminal prosecutions generate but also by cost cutting in a competitive medical market. Physicians can respond positively by strengthening licensing boards, articulating and following reasonable standards of care, and developing more effective injury-prevention programs. Responsible physicians have nothing to fear from the criminal law. When physicians intentionally or recklessly disregard their patients' safety, however, they properly face criminal prosecution.

\section{REFERENCES}

1. Leape LL. Error in medicine. JAMA 1994;272:1851-7.

2. Brennan TA, Leape LL, Laird NM, et al. Incidence of adverse events and negligence in hospitalized patients - results of the Harvard Medical Practice Study I. N Engl J Med 1991;324:370-6.

3. Glantz LH. Withholding and withdrawing treatment: the role of the criminal law. Law Med Health Care 1987-88;15:231-41.

4. Malpractice or homicide? Washington Post. April 18, 1995:A16.

5. Nossiter A. A mistake, a rare prosecution, and a doctor is headed for jail. New York Times. March 16, 1995:A1.

6. People v. Einaugler, 618 N.Y.S.2d 414 (App. Div. 2d Dept. 1994)

7. Capron AM. Punishing medicine. Hastings Cent Rep 1995;25(3):26-7.

8. Holloway L. Trial of doctor in botched abortion starts. New York Times. July 14, 1995:B3.

9. In the matter of Joseph J. Verbrugge, MD, Colorado Board of Examiners, No. ME 93-06 (May 17, 1994).

10. Pankratz H. Former doctor charged with manslaughter. Denver Post. April 6, 1995:B1

11. Kolata G. Medical laboratory faces charges in cancer deaths. New York Times. April 13, 1995:A16.

12. Voelker R. Milwaukee deaths reignite critical issues in cervical cancer screening. JAMA 1995;273:1559-60.

13. Brahams D. Doctors and manslaughter. Lancet 1993;341:1404

14. In the matter of Spring, 380 Mass. 629, 637 (1980).

15. Barret DC. Anno, Homicide predicated on improper treatment of disease or injury. 45 ALR3d 114-179.

16. People v. Klvana, 15 Cal. Rptr. 2d 512, 526 (App. 2d Dist. 1992).

17. New Jersey v. Weiner, 194 A.2d 467 (N.J. 1963).

18. Commonwealth v. Youngkin, 427 A.2d 1356 (Pa. Super. 1981).

19. Harrington MP. Health care crimes: avoiding overenforcement. Rutgers Law J 1994;26:111-53.

\section{BOOK REVIEWS}

\section{Community Ghild Health: An aGtion Plan for TODAY}

By Judith S. Palfrey. 302 pp. Westport, Conn., Praeger, 1994. \$55. ISBN 0-275-94696-7.

Judith Palfrey has written a well-organized, readable book about children's health as it is affected by forces in the community. Physicians, social workers, and community health workers, as well as politicians and others who shape public policy, would benefit from reading it.

Palfrey leads the reader to conclude that we have entered a new era in child health. She divides the 20th century into the initial classic period, when physiologic investigation and technological innovation led to remarkable improvements in nutrition, the treatment of infectious diseases, and approaches to prematurity, and the second period, characterized by the "new morbidity," with attention to psychosocial and educational concepts. Palfrey introduces us to a third period, in which children suffer from epidemics of violence, acquired immunodeficiency syndrome, homelessness, and social disorder. She also includes the increasing numbers of survivors of chronic disease, children who initially benefited from hightechnology care but who are now left with the chronic aftermath. She portrays the present status of childhood health with brief, practical clinical vignettes and suggests how child health workers could involve the community in attacking these problems. She advocates an inclusive approach that would extend far beyond individual practitioners and even beyond the established teams of hospital-based physicians, nurses, social workers, and dietitians in large cities. She invites teachers, community members, and others to help solve the problems children face in their homes, neighborhoods, and schools.

Drawing on 20 years of experience in the communityhealth arena in Boston, Palfrey gives detailed plans of action. Concrete examples include averting teenage pregnancy, controlling infection in a group home, and caring for preschoolers with chronic illness. The last chapters encourage community political action to improve the lot of children. They explore the political realities that hamper even well-meaning attempts to assist children living in poverty or in disrupted families, children in violent environments and foster and group care, and children with chronic diseases. The author's message is one of optimism, in spite of widespread problems facing such children. Her prescription is for a focused approach, often starting with small, achievable goals and established granting agencies. A team may then build on their successes and pursue more ambitious needs. The book clearly identifies many resources, each chapter has a large supply of endnotes, and a 29-page bibliography ensures that this is a practical tool.

Palfrey is a leader in applying the resources of Children's Hospital of Boston, well known for highly technical tertiary care activities, to the preventive and continuing-care issues of 